\title{
Opioid and Endocannabinoid System in Orofacial Pain
}

\author{
M. ZUBRZYCKI ${ }^{1}$, M. STASIOLEK ${ }^{2}$, M. ZUBRZYCKA ${ }^{3}$ \\ ${ }^{1}$ Department of Cardiovascular and Thoracic Surgery, University of Ulm, Ulm, Germany, \\ ${ }^{2}$ Department of Neurology, Medical University of Lodz, Lodz, Poland, ${ }^{3}$ Department of \\ Cardiovascular Physiology, Interdepartmental Chair of Experimental and Clinical Physiology, \\ Medical University of Lodz, Lodz, Poland
}

Received March 3, 2019

Accepted May 20, 2019

Epub Ahead of Print August 19, 2019

\section{Summary}

Orofacial pain disorders are frequent in the general population and their pharmacological treatment is difficult and controversial. Therefore, the search for novel, safe and efficient analgesics is an important but still elusive goal for contemporary medicine. In the recent years, the antinociceptive potential of endocannabinoids and opioids has been emphasized. However, concerns for the safety of their use limit their clinical applications. the possibility of modulating the activity of endocannabinoids by regulation of their synthesis and/or degradation offers an innovative approach to the treatment of pain. A rat model of trigeminal pain, utilizing tongue jerks evoked by electrical tooth pulp stimulation during perfusion of the cerebral ventricles with various neurotransmitter solutions can be used in the pharmacological studies of nociception in the orofacial area. The aim of this review is to present the effects of pharmacological activity of opioids and endocannabinoids affecting the transmission of the sensory information from the orofacial area on the example of trigemino-hypoglossal reflex in rats.

\section{Key words}

Orofacial pain - Opioid and cannabinoid receptors • Endocannabinoid system - Perfusion of cerebral ventricles • Trigemino-hypoglossal reflex

\section{Corresponding author}

M. Zubrzycka, Department of Cardiovascular Physiology, Interdepartmental Chair of Experimental and Clinical Physiology, Medical University of Lodz, Mazowiecka 6/8, 92-215, Lodz, Poland. E-mail: maria.pawelska-zubrzycka@umed.lodz.pl

\section{Introduction}

The therapy of pain is currently one of the challenges of modern medicine. Orofacial pain disorders are frequent in the general population and their pharmacological treatment is difficult and controversial (Weiss et al. 2017). This is due in part to limited understanding of the pathophysiology of the pain disorders that arise from the structures innervated by the trigeminal nerve. The additional reasons include the paucity of animal models, which allow to evaluate the responsiveness of nociceptors the magnitude of nociceptive reaction by measuring baseline and stimulated release of neuropeptides during the activation of trigeminal afferents (Hargreaves 2011, Zubrzycka and Janecka 2002, Zubrzycka and Janecka 2011).

In recent years, an accumulating body of evidence has suggested the potential use of endocannabinoids and opioids as the modulators of orofacial pain transmission (Zubrzycka et al. 2011, Zubrzycka et al. 2017).

It has been demonstrated that the endogenous opioid system could be involved in cannabinoid antinociception and recent data have also provided evidence for a role of the endogenous cannabinoid system in opioid antinociception (Bushlin et al. 2010, Cichewicz 2004, Wilson-Poe et al. 2013).

Opioids and cannabinoids produce antinociception through separate (although possibly interrelated) mechanisms (Cichewicz 2004, Roberts et al. 2006, Tham et al. 2005). 
They also exhibit overlapping neuroanatomical distribution and comparable functional neurobiological properties (Nawarro et al. 2001). Both receptor types are found in several brain regions known to participate in antinociception, including the periaqueductal central gray (PAG), raphe nuclei and central medial thalamic nuclei (Cichewicz 2004, Manzanares et al. 1999). Furthermore, $\mu$ - and CB1 receptors have been shown to colocalize to the same neurons within the superficial dorsal horn of the spinal cord, the first site of synaptic contact for peripheral nociceptive afferents, raising the possibility of direct interactions between these receptor types on the same cell (Hohmann et al. 2005, Salio et al. 2001).

Interestingly, CB1 receptors can exist as homodimers and they may also form heterodimers or oligomers with one or more other classes of co-expressed GPCRs, in a manner that may lead to cross-talk between CB1 receptors and noncannabinoid sites (Pertwee 2006).

Interactions between endocannabinoids (ECs) and the opioid system during antinociception have been evaluated using cannabinoid receptor antagonists or inhibitors of enzymes that degrade ECs. Studies showing that treatment with cannabinoid receptor agonists can lead to opioid peptide release and that ECs are involved in the actions of opioid agonists confirm the synergistic interactions between these two receptor systems (Cichewicz 2004, Lau et al. 2014a).

It is generally accepted that tooth pulp stimulation in rats represents a valuable pain model and has been proposed as a model for trigeminal pain (Chapman et al. 1986).

The trigemino-hypoglossal reflex has been used in research on the properties of neuropeptides perfused through the cerebral ventricles. In this pain model, the amplitude of the evoked tongue jerks (ETJ) induced by tooth pulp stimulation is recorded. The magnitude of ETJ during perfusion of the cerebral ventricles with the neurotransmitters under investigation can be a measure of the effect of these compounds on the neural structures (Zubrzycka et al. 1997, Zubrzycki et al. 2015).

The pharmacology and molecular mechanisms of sensory transmission in the trigeminal system have not been fully identified so far, which is associated with the lack of effective treatment for pain syndromes originating from the orofacial area.

Therefore, the aim of this review is to present the effect of pharmacological activity of opioids and endocannabinoids affecting the transmission of sensory information from the orofacial area on the example of trigemino-hypoglossal reflex in rats.

\section{The opioid system}

The opioidergic system consists of opioid receptors and their peptide ligands. Opioid receptors were discovered approximately 40 years ago and they belong to the G-protein coupled receptor (GPCR) family. The heterogeneity of opioid receptors and the existence of at least three main opioid receptor types, designated as $\mu, \delta$ and $\kappa$ (or MOR, DOR and KOR, respectively) is widely accepted (Kieffer 1995). Opioid receptors and endogenous opioid peptides are most abundant in the central nervous system (CNS) but are also localized in many peripheral tissues of the mammalian organism (Le Merrer et al. 2009).

Opioid receptors can be activated by exogenous opiates, such as morphine and its derivatives, as well as by endogenous opioid peptides: enkephalins (ENK), dynorphins (DYN), $\beta$-endorphin $(\beta$-END) and endomorphins (EMs), which are the family of neurochemical messengers that exhibit high affinity for one or more of the opioid receptors (Przewlocki and Przewlocka 2001, Rokyta 2018).

Opiates exert their antinociceptive activity by activation of the $\mu$-opioid receptors. Therefore, the search for natural and synthetic ligands of this receptor has become an attractive goal. The discovery in 1997 of two endogenous ligands of the $\mu$-opioid receptor, endomorphin-1 (Tyr-Pro-Trp-Phe-NH2) and endomorphin-2 (Tyr-Pro-Phe-Phe-NH2), gave hope that they could be used as analgesics devoid of at least some of undesired side effects of morphine (Zadina et al. 1997).

However, the use of endomorphins (EMs) as analgesics is of little therapeutic value because these peptides are quickly degraded by enzymes and have a very limited ability to penetrate the blood-brain barrier (BBB) effectively due to their small size and hydrophilic nature. To overcome the limited access of exogenously administered EMs to the brain, numerous chemical modifications of their structure have been proposed. To date, the structure of endomorphins has been modified by the introduction of D-amino acids and unnatural amino acids with $\mathrm{L}$ and $\mathrm{D}$ configurations, or by cyclization of the linear sequences (Perlikowska et al. 2014).

\section{The endocannabinoid system}

The endogenous cannabinoid system (ECS), which consists of three principal components, i.e. "classical" cannabinoids (CB1, CB2) and "non-classical" (TRPV1, GPR55, PPARs) receptors, endogenous ligands 
(anandamide, AEA; 2-arachidonyloglycerol, 2-AG) and enzymes, responsible for $\mathrm{CB}$ synthesis and degradation, has recently attracted much attention as a crucial site in pain pathophysiology (Fonseca et al. 2013). Both CB1 and CB2 receptors which are both GPCRs inhibit the activity of adenylyl cyclase (Kaminski 1996) and activate mitogen-activated protein (MAP) kinases (Bouaboula et al. 1995). Additionally, CB1 (Mackie and Hille 1992) and CB2 receptors (Atwood et al. 2012) inhibit the function of voltage gated calcium channels, while only CB1 receptors have been shown to modulate the activity of potassium channels (Hampson et al. 1995).

The CB1 receptors exist predominantly in the $\mathrm{CNS}$, at central and peripheral nerve terminals, where they mediate inhibition of transmitter release (Fride 2002). CB2 receptors occur mainly in the peripheral locations in the cells and organs associated with the immune system and are involved in the control of inflammatory reactions, one of their roles being the modulation of cytokine release (Pandey et al. 2009). Thus, a common role of CB1 and CB2 receptors appears to be the modulation of ongoing release of chemical messengers from neurons or from immune cells, respectively.

Identification of cannabinoid receptors started the search for their endogenous ligands and changed the initial belief that cannabinoids are substances of exclusively plant origin. In 1992, Devane et al. described the isolation of a brain lipid, arachidonoyl ethanolamide, named AEA, which mimicked the behavioral actions of the plant-derived THC. AEA is a partial agonist of both, $\mathrm{CB} 1$ and $\mathrm{CB} 2$ receptors but has lower efficacy and affinity for $\mathrm{CB} 2$ than for $\mathrm{CB} 1$.

Mechoulam et al. (1995) and Sugiura et al. (1995), independently, identified a second endocannabinoid, 2-AG which turned out to be a full CB1 receptor agonist and has higher affinity and efficacy for CB1 and $\mathrm{CB} 2$ receptors than AEA. Both endocannabinoids are derivatives of arachidonic acid conjugated with either ethanolamine (AEA) or with glycerol (2-AG).

There are some other lipid substances isolated from the brain, which have affinity for $\mathrm{CB} 1$ or $\mathrm{CB} 2$ receptors. However, their affinity is much lower than that of classical endocannabinoids, AEA or 2-AG, and they are considered putative ligands of these receptors or cannabinoid-like compounds. They may probably act together with endocannabinoids, by inhibiting their inactivation. Among such cannabinoid-like compounds there is, more recently discovered, O-arachidonoyl ethanolamine (virodhamine) which is an ester of arachidonic acid and ethanolamine, as opposed to the amide linkage found in AEA. It acts as an antagonist of $\mathrm{CB} 1$ receptor and agonist of $\mathrm{CB} 2$ receptor. Other important fatty acid amides related to endocannabinoids are oleoylethanolamide (OEA), an agonist of the CB1 receptor and palmitoylethanolamide (PEA), a selective CB2 receptor agonist (Di Marzo et al. 2001).

However, much attention has currently been given to the fatty acid amide hydrolase (FAAH) and its metabolites. FAAH is an intracellular enzyme, primarily located in the brain and the liver, as well as in peripheral organs (Ueda and Yamamoto 2000). It is commonly accepted that AEA is the main substrate for FAAH, but a growing body of evidence points that 2-AG, although not exclusively, is also deactivated by this hydrolase (Di Marzo et al. 2001). FAAH is also involved in the degradation of several other biolipids, including OEA and PEA, which may bind to both, "classical" and "nonclassical" CB receptors. Therefore, it has been suggested that the modulators of the FAAH activity, as potential therapeutics, may provide finer tuning of the ECS function than the $\mathrm{CB}$ receptor ligands, also in terms of peripheral vs. central site-dependent side effects (Hanus and Mechoulam 2010).

Cannabinoids act synergistically with opioids and act as opioid-sparing agents, allowing lower doses and fewer side effects from chronic opioid therapy. The endocannabinoid system represents an ideal target because it is a key endogenous system in modulating pain-processing pathways (Mechoulam et al. 2014, Woodhams et al. 2017, Rokyta et al. 2018).

\section{Common features of opioid and cannabinoid receptor systems}

There is considerable evidence describing similarities between the opioid receptor system and the cannabinoid receptor system. Activation of opioid or cannabinoid receptors can produce similar behavioral effects, including antinociception, suggesting a similar distribution and mechanism of action (Manzanares et al. 1999, Woodhams et al. 2017). Both receptor types are found in several brain regions known to participate in antinociception, including PAG, raphe nuclei and centralmedial thalamic nuclei, suggesting that they may either act alone, or in tandem to produce antinociception (Hohmann et al. 1999). Furthermore, $\mu$ - and CB1 receptors have been shown to colocalize to the same neurons within the superficial dorsal horn of the spinal cord (Hohmann et al. 1999, Salio et al. 2001), the first 
site of synaptic contact for peripheral nociceptive afferents, raising the possibility of direct interactions between these receptor types within the same cell.

Opioid and cannabinoid receptors also share similar signal transduction properties. Both are GPCRs that 1) couple to Gai, blocking cAMP production, 2) activate MAP kinases through other second messenger systems, and 3) inhibit neurotransmitter release via inhibition of calcium channels and activation of potassium channels (Cichewicz 2004, Vigano et al. 2005). Both receptors types are generally found on presynaptic terminals, a location that is consistent with the inhibition of neurotransmitter release (Vigano et al. 2005, Rokyta 2018). These data raise the intriguing possibility that opioid and cannabinoid receptors function together within the same cell or neuronal circuit to produce antinociception and that modulation of one receptor system may lead to alterations in the activity of the other.

\section{Neuronal organization of trigemino-hypo- glossal reflex}

The reflex that has been used for over a decade in research of the properties of neuropeptides perfused through the cerebral ventricles in rats is the evoked tongue jerk (ETJ) due to trigemino-hypoglossal reflex (Zubrzycka et al. 1997, Zubrzycki et al. 2017).

The trigemino-hypoglossal reflex arc extends below the floor of the IV ventricle between the sensory nucleus of the trigeminal nerve and the motor nucleus of the hypoglossal nerve (Fig. 1).

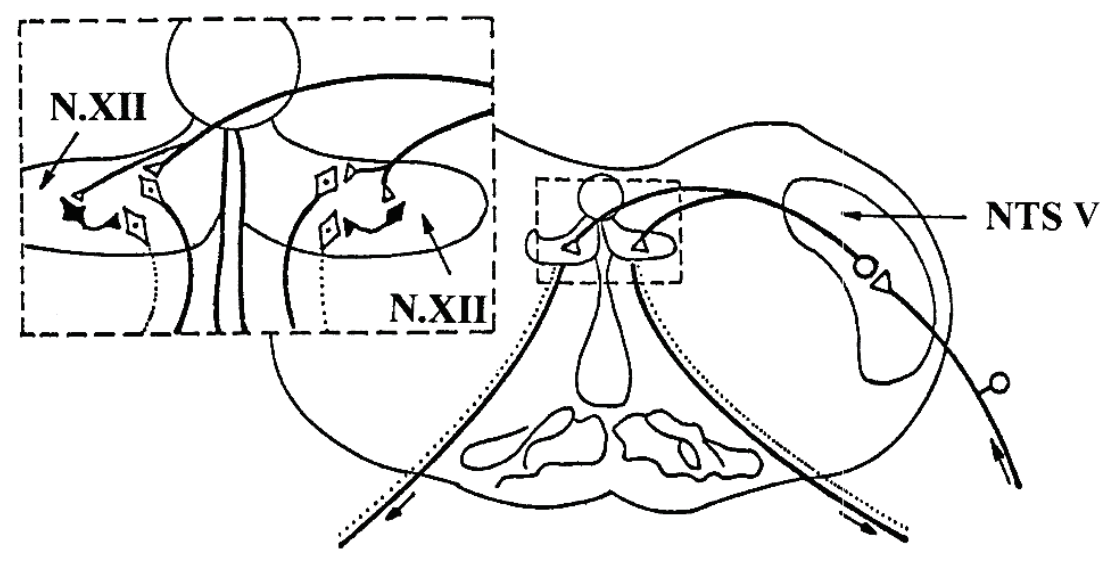

Fig. 1. A scheme of the trigeminohypoglossal reflex arc. NTS V - n.V spinal tract nucleus; N.XII hypoglossal nerve nucleus; light-colored triangle - the excitatory synapse, dark triangle - the inhibitory synapse.

The hypoglossal nerve nucleus is situated superficially under the floor of the fourth cerebral ventricle, which allows to suppose that chemical substances can penetrate to that nucleus from the IV ventricle lumen faster than to the motor trigeminal nerve nucleus, located deeper under the floor of the IV ventricle. The magnitude of the trigemino-hypoglossal reflex and the factor modulating the reflex depend on the branch of the trigeminal nerve, whose stimulation with electric impulses evokes contractions of the tongue muscles. The recorded amplitude of ETJ induced by tooth pulp stimulation is the measure of the effect of neuropeptides on the neural structures (Zubrzycka et al. 1997). The variability of effects of neuropeptides perfused through the cerebral ventricles of the trigeminohypoglossal reflex can be explained by their different impact on the sensory neurons of $\mathrm{n} . \mathrm{V}$ nuclei, interneurons and n.XII motoneurons. The stimulating or inhibitory effect is dependent on the binding site of the investigated compound with the membrane receptor, the time of its release from the receptor, as well as its degradation time.

In the trigemino-hypoglossal reflex such as tongue jerk evoked by tooth pulp stimulation, the impulsation from n.V sensory nuclei was transferred to the ipsi- and contralateral hypoglossal nerve nucleus where it stimulated the motoneuron of the tonguewithdrawing muscles, and by excitation of the inhibitory interneuron caused inhibition of the tongue protrusion muscles motoneuron.

As indicated by the results of experiments involving perfusion of neuropeptides through the cerebral ventricles in rat obtained to date, the trigeminohypoglossal reflex may serve as a good model for testing the effect of various neuropeptides on the brainstem centers.

\section{Neuropeptides in the cerebrospinal fluid}

The cerebroventricular system may play the role of a humoral information channel in the CNS. The 
cerebrospinal fluid (CSF), although it is not likely to contain biologically active endogenous neuropeptides, can be used as a vehicle to transport exogenous neuropeptides across the ependyma into the brain parenchyma following intracerebroventricular (i.c.v.) administration. Thus, due to the reversed concentration gradient following administration, exogenous neuropeptides in the CSF can potentially reach numerous, even very distant, locations within the brain (Bittencourt and Sawchenko 2000).

A neuropeptide which is administered i.c.v. is first diluted in the CSF, and then diffuses through the whole area of the ventricular and cerebellomedullary cistern walls into the ECF of the brain. From the ECF, it diffuses towards the target site, i.e. into the vicinity of structures responsible for the trigemino-hypoglossal reflex. Hence, the ultimate concentration of the neuropeptide following i.c.v. administration, which is effective in the specific structures, is significantly lower than the initial concentration.

Whether or not will the neuropeptide reach the brain, is largely dependent on its ability to cross the BBB, which depends on its lipophilic properties. Hydrophilic compounds penetrate that barrier less effectively. Opioids characterized by high lipophilicity permeate to the brain more easily (Abbott 2002).

Noxius stimuli may increase the release of endogenous opioid peptides, including $\beta$-endorphin ( $\beta$-EP), in the midbrain PAG and in the hypothalamus, as well as their release to the CSF (Bach et al. 1995).

As demonstrated by clinical studies, the endorphin levels in the CSF may increase after stimulation with low-frequency alternating current. Stimulation of tooth pulp and nociceptive fibers results in a significant increase in the release of immunoreactive $\beta$-EP (Zubrzycka and Janecka 2011). The fibers containing $\beta$-EP are widely distributed in the brain and terminate in $\mathrm{PAG}$, but their main projections extend along the cerebral ventricles, where they are in close contact with the ependyma of the third ventricle and the CSF-containing neurons (Veening and Barendregt 2010). Therefore, active transport of neuropeptides into the CSF might be effected via specialized ependymal cells tanycytes, extending from the third ventricle, where the sensory and motor centers of the trigemino-hypoglossal reflex are situated (Langlet et al. 2013). Also CB2 receptor activation by AM1241 causes a release of $\beta$-EP from keratinocytes, and the antinociceptive effect of AM1241 in rats is blocked by $\mu$-opioid receptor antagonism and by $\beta$-EP antiserum (Ibrahim et al. 2005).

Some endocannabinoids have been shown to play a role in the regulation of BBB permeability. It has been demonstrated that AEA and OEA decrease BBB permeability in vitro in human cells in normal conditions (Hind et al. 2015). Used in in vivo and in vitro models, they increased BBB permeability following chronic head injury and multiple sclerosis decreased by the exogenous addition of AEA (Mestre et al. 2011) and 2-AG (Panikashvili et al. 2006).

In view of the above, changes of CSF composition should influence the somatic reflex whose centers are located in the vicinity of the cerebral ventricles.

\section{Effect of opioids on the trigemino- hypoglossal reflex}

Endogenous opioid systems play an important role in the antinociceptive activity (Rokyta 2018). The involvement of opioid receptors in neuropeptide-induced modulation of the trigemino-hypoglossal reflex was confirmed by blocking of these receptors with naloxone (NAL) or a selective $\mu$-receptors antagonist $\beta$-funaltrexamine ( $\beta$-FNA) (Zubrzycka et al. 2005, Zubrzycka and Janecka 2008, Zubrzycka and Janecka 2011). Activation of PAG neurons is associated with the descending antinociceptive effect (Bourbia and Pertovaara 2018). Blocking with NAL the opioid receptors located in the centers adjacent to the cerebral ventricles disinhibited to a considerable extent the nociceptive trigemino-hypoglossal reflex due to PAG stimulation, which inhibits the reflex. The above evidences the role of opioid receptors in modulation of the reflex magnitude (Zubrzycka and Janecka 2001, Zubrzycka and Janecka 2011).

It has also been demonstrated that blocking opioid receptors in the centers adjacent to the cerebral ventricles with exogenous morphiceptin, ENK-Met, $\beta$-EP, EM-2 and based on the structure of EM-2 cyclic pentapeptide Tyr-c[D-Lys-Phe-Phe-Asp] $\mathrm{NH}_{2}$, (cEM-2), abolishes to a considerable extent the nociceptive ETJ reflex induced by tooth pulp stimulation in rats (reducing the magnitude of the reflex) (Zubrzycka and Janecka 2008, Zubrzycka and Janecka 2011, Zubrzycki et al. 2017).

Immunohistochemical studies have demonstrated that ENK-ergic neurons do not form pathways within the brain, but they occur in clusters as interneurons. Such 
clusters have been observed both in the vicinity of the n.V spinal tract nucleus (NTS V) (Petrusz et al. 1985) and the n.XII nucleus (Connaughton et al. 1986). The presence of these neurons and ENK-ergic receptors on the cell membranes of n.XII nucleus motoneurons explains the inhibition of ETJ during perfusion of the cerebral ventricles with ENK.

EM-2 inhibits the amplitude of ETJ more intensively than morphiceptin and ENK-Met. The most potent antinociceptive properties have been demonstrated for cEM-2, which shows high affinity to the $\mu$ - and CB1 receptors. Such an effect is associated with the fact that cyclization reduces the molecular conformational freedom, which is responsible for the activation of different receptors, increases metabolic stability and may increase lipophilicity, which often improves the bloodbrain barrier BBB permeability for peptides (Zubrzycka and Janecka 2008, Zubrzycki et al. 2017).

\section{Effect of cannabinoids on the trigemino- hypoglossal reflex}

Several lines of evidence have recently suggested that opioid and cannabinoid receptors can functionally interact in the CNS. These interactions may be direct, through receptor heteromerization, or indirect, through signaling cross-talk that includes agonistmediated release and/or synthesis of endogenous ligands that can activate the downstream receptors (Bushlin et al. 2012).

Studies on the mechanisms underlying the analgesic effects of opioids and cannabinoids have largely focused on the GABA-ergic system within the PAG. Like opioids, cannabinoids are thought to produce analgesia by suppressing GABA-ergic inhibition of PAG output neurons, which project along a descending analgesic pathway (Lau et al. 2014b). ECs are described as 'synaptic circuit breakers' (Katona and Freund 2012), acting as retrograde neurotransmitters in the PAG and rostral ventromedial medulla, inhibiting GABA-ergic and glutamatergic transmission by preventing the release of transmitters from nerve terminals, via activation of CB1Rs (Vaughan et al. 1999).

The role of the endocannabinoid system in orofacial pain has also been investigated, demonstrating that the $\mathrm{CB} 1$ receptor ligand AEA exerts its analgesic effect via $\mathrm{CB} 1$ and $\mu$ - receptors (Zubrzycki et al. 2017).

$\mathrm{CB} 1$ receptors are localized on fibres in the spinal trigeminal tract, found on large diameter myelinated fibres and in the nucleus trigeminalis caudalis (Price et al. 2003). Therefore, it is also possible that AEA exerts a direct effect upon trigeminal neurons (Akerman et al. 2004) to cause inhibition of CGRP (calcitonine gene-related peptide) release from central terminals of primary afferent fibres and to reduce the nociceptive behaviour.

Blocking opioid and cannabinoid receptors with their antagonists ( $\beta$-FNA and AM251) resulted in a significant decrease in the antinociceptive activity of AEA, confirming the involvement of opioid and cannabinoid systems in the modulation of the trigeminohypoglossal reflex (Zubrzycki et al. 2017). As the elements involved in the trigemino-hypoglossal reflex arc are located in the vicinity of the cerebral ventricles, it can be assumed that $\beta$-FNA and AM251 injected into the cerebral ventricles permeated through the cerebroventricular lining and exerted their effects on the adjacent structures.

What seems surprising is that 2-AG had no significant effect on the amplitude of ETJ (Zubrzycki et al. 2017), as the PAG contains higher 2-AG than AEA levels under basal conditions (Maione et al. 2006, Petrosino et al. 2007). Furthermore, 2-AG has a higher efficacy as a full $\mathrm{CB} 1$ receptor agonist, despite the lower receptor affinity compared to AEA (Luk et al. 2004). This lower efficacy of 2-AG observed in our experiments might be due to the lower levels of 2-AG accessing presynaptic $\mathrm{CB} 1$ receptors and also to the fact that degradative enzyme for $2-A G$ is in closer proximity to the target $\mathrm{CB} 1$ receptor than AEA.

The literature data indicate that both AEA and 2-AG can independently regulate pain sensation (Lau et al. 2014b, Long et al. 2009a) and suggest that their individual activities are profoundly augmented upon simultaneous blockade of their respective degradative enzymes.

To verify this hypothesis in our pain model, we used the selective FAAH and MAGL (monoacylglycerol lipase) inhibitors URB597 and JZL184 respectively. URB597 shows high specificity for FAAH, significantly elevating the levels of AEA, OEA and PEA in the CNS and in peripheral tissues. PEA and OEA are capable of elevating the levels of AEA through substrate competition at FAAH (Alhouayek and Muccioli 2008, Kathuria et al. 2003).

In our experiments, we determined that inhibition of FAAH most likely resulted in an increase in AEA levels and enhanced antinociceptive effects. On the 
other hand, inhibition of MAGL had no effect on the antinociceptive activity of 2-AG (Zubrzycki et al. 2017). Given the fact that FAAH and MAGL are localized in different regions of the neuron (e.g. FAAH postsynaptically, MAGL presynaptically) and regulate different ECs, the possibility exists that they may have different roles in regulating physiological functions, including nociception. It was shown that in acute pain models, effects of MAGL inhibition appear to be largely mediated by CB1 receptors (Long et al. 2009a), though a more prominent CB2-mediated component has been identified in inflammatory and neuropathic pain models (Guindon and Hohmann 2008), perhaps unsurprisingly since $2-A G$ is a full agonist at $\mathrm{CB} 2$ receptors while AEA is only a weak partial agonist of this receptor (Gonsiorek et al. 2000). Full inhibition of MAGL via JZL184 produces many cannabinoid-like behaviors (Long et al. 2009a), suggesting that this approach may share some of the unwanted side effects of cannabinoids. Furthermore, several studies have now revealed that sustained global elevation of 2-AG via genetic deletion of MAGL or persistent blockade of MAGL activity with enzyme inhibitors produces functional antagonism of the brain EC system (ECS), resulting in a profound downregulation and desensitization of $\mathrm{CB} 1$ receptors in nociception-associated regions, and a loss of analgesic phenotype (Imperatore et al. 2015, Navia-Paldanius et al. 2015).

Long et al. (2009b) developed a new antagonist, JZL195, with dual inhibitory properties, simultaneously at MAGL and FAAH. Such inhibition might offer an attractive therapeutic approach, allowing to maintain analgesic efficacy at significantly lower doses while minimizing side effects associated with the direct action of cannabinoid agonists.
Our results indicated that JZL195 enhanced the antinociceptive activity, most likely through the pharmacological elevation of AEA levels in the brain, and had greater antinociceptive efficacy than selective FAAH or MAGL inhibitors (Zubrzycki et al. 2017). Similar results were published by Long et al. (2009b), who showed that administration of JZL195 to mice resulted in reduction of brain FAAH and MAGL activities that correlated with near-complete inhibition of both AEA and 2-AG hydrolysis. These effects were accompanied by dramatic elevations of AEA and 2-AG brain levels that approximated the increases observed with selective FAAH (URB597) or MAGL (JZL184) inhibitors.

Thus, the possibility of modulating the activity of endocannabinoids by regulation of their synthesis and/or degradation offers an innovative therapeutic approach in many pathologic conditions (Hanus and Mechoulam 2010).

In conclusion, our data show that $\mathrm{EC}$ and opioid pathways are involved in the descending modulatory control of trigeminal nociceptive transmission from the brainstem, a mechanism hypothesized to contribute to the pathophysiology of orofacial pain. Additionally, these effects may imply that AEA, EM-2 and inhibitors of FAAH and FAAH/MAGL could be therapeutic in orofacial pain. Clinically, the data may offer the promise of an interesting avenue for therapeutic development.

\section{Conflict of Interest}

There is no conflict of interest.

\section{Acknowledgements}

The study was supported by a grant no. 503/1-07903/503-11-001-18 from the Medical University of Lodz.

\section{References}

ABBOTT NJ: Astrocyte-endothelial interactions and blood-brain barrier permeability. J Anat 200: 629-638, 2002.

AKERMAN S, KAUBE H, GOADSBY PJ: Anandamide is able to inhibit trigeminal neurons using an in vivo model of trigeminovascular-mediated nociception. J Pharmacol Exp Ther 309: 56-63, 2004.

ALHOUAYEK M, MUCCIOLI GG: Harnessing the anti-inflammatory potential of palmitoylethanolamide. Drug Discov Today 19: 1632-1639, 2008.

ATWOOD BK, STRAIKER A, MACKIE K: $\mathrm{CB}(2)$ cannabinoid receptors inhibit synaptic transmission when expressed in cultured autaptic neurons. Neuropharmacol 63: 514-523, 2012.

BACH FW, CHAPLAN SR, JANGJ, YAKSH TL: Cerebrospinal fluid $\beta$-endorphin in models of hyperalgesia in the rat. Regul Pept 59: 79-86, 1995.

BITTENCOURT JC, SAWCHENKO PE: Do centrally administered neuropeptides access cognate receptors? An analysis in the central corticotropin-releasing factor system. J Neurosci 20: 1142-1156, 2000. 
BOUABOULA M, POINOT-CHAZEL C, BOURRIE B, CANAT X, CALANDRA B, RINALDI-CARMONA M, LE FUR G, CASELLAS P: Activation of mitogen-activated protein kinases by stimulation of the central cannabinoid receptor CB1. Biochem J 312: 637-641, 1995.

BOURBIA N, PERTOVAARA A: Involvement of the periaqueductal gray in the descending antinociceptive effect induced by the central nucleus of amygdala. Physiol Res 67: 647-655, 2018.

BUSHLIN I, ROZENFELD R, DEVI LA: Cannabinoid-opioid interactions during neuropathic pain and analgesia. Curr Opin Pharmacol 10: 80-86, 2010.

BUSHLIN I, GUPTA A, STOCKTON SD JR, MILLER LK, DEVI LA: Dimerization with cannabinoid receptors allosterically modulates delta opioid receptor activity during neuropathic pain. PLoS One 7: e49789, 2012.

CHAPMAN CR, GERLACH R, JACOBSON R, BUFFINGTON V, KAUFMANN E: Comparison of short-latency trigeminal evoked potentials elicited by painful dental and gingival stimulation. Electroencephalogr Clin Neurophysiol 65: 20-26, 1986.

CICHEWICZ DL: Synergistic interactions between cannabinoid and opioid analgesics. Life Sci 74: 1317-1324, 2004.

CONNAUGHTON M, PRIESTLEY JV, SOFRONIEW MV, ECKENSTEIN F, CUELLO AC: Inputs to motoneurones in the hypoglossal nucleus of the rat: light and electron microscopic immunocytochemistry for choline acetyltransferase, substance $P$ and enkephalins using monoclonal antibodies. Neuroscience 17: 205-224, 1986.

DEVANE WA, HANUŠ L, BREUER A, PERTWEE RG, STEVENSON LA, GRIFFIN G, GIBSON D, MANDELBAUM A, ETINGUER A, MECHOULAM R: Isolation and structure of a brain constituent that binds to the cannabinoid receptor. Science 258: 1946-1949, 1992.

Di MARZO V, De PETROCELLIS L, BISOGNO T: Endocannabinoids Part I: molecular basis of endocannabinoid formation, action and inactivation and development of selective inhibitors. Expert Opin Ther Targets 5: 241-265, 2001.

FONSECA BM, COSTA MA, ALMADA M, CORREIA-DE-SILVA G, TEIXEIRA NA: Endogenous cannabinoids revisited: a biochemistry perspective. Prostaglandins Other Lipid Mediat 102-103: 13-30, 2013.

FRIDE E: Endocannabinoids in the central nervous system-an overview. Prostaglandins Leukot Essent Fatty Acids 66: 221-233, 2002.

GONSIOREK W, LUNN C, FAN X, NARULA S, LUNDELL D, HIPKIN RW: Endocannabinoid 2-arachidonyl glycerol is a full agonist through human type 2 cannabinoid receptor: antagonism by anandamide. $\mathrm{Mol}$ Pharmacol 57: 1045-1050, 2000.

GUINDON J, HOHMANN AG: Cannabinoid CB2 receptors: a therapeutic target for the treatment of inflammatory and neuropathic pain. Br J Pharmacol 153: 319-334, 2008.

HAMPSON RE, EVANS GJ, MU J, ZHUANG SY, KING VC, CHILDERS SR, DEADWYLER SA: Role of cyclic AMP dependent protein kinase in cannabinoid receptor modulation of potassium "A-current" in cultured rat hippocampal neurons. Life Sci 56: 2081-2088, 1995.

HANUŠ L, MECHOULAM R: Novel natural and synthetic ligands of the endocannabinoid system. Curr Med Chem 17: 1341-1359, 2010.

HARGREAVES KM: Orofacial pain. Pain 152 (3 Suppl): S25-S32, 2011.

HIND WH, TUFARELLI C, NEOPHYTOU M, ANDERSON SI, ENGLAND TJ, O'SULLIVAN SE: Endocannabinoids modulate human blood-brain barrier permeability in vitro. Br J Pharmacol 172: 3015-3027, 2015.

HOHMANN AG, BRILEY EM, HERKENHAM M: Pre- and postsynaptic distribution of cannabinoid and mu opioid receptors in rat spinal cord. Brain Res 822: 17-25, 1999.

IBRAHIM MM, PORRECA F, LAI J: CB2 cannabinoid receptor activation produces antinociception by stimulating peripheral release of endogenous opioids. Proc Natl Acad Sci U S A 102: 3093-3098, 2005.

IMPERATORE R, MORELLO G, LUONGO L, TASCHLER U, ROMANO R, DE GREGORIO D, BELARDO C, MAIONE S, DI MARZO V, CRISTINO L: Genetic deletion of monoacylglycerol lipase leads to impaired cannabinoid receptor CB1R signaling and anxietylike behavior. J Neurochem 135: 799-813, 2015.

KAMINSKI NE: Immune regulation by cannabinoid compounds through the inhibition of the cyclic AMP signaling cascade and altered gene expression. Biochem Pharmacol 52: 1133-1140, 1996. 
KATHURIA S, GAETANI S, FEGLEY D, VALIÑO F, DURANTI A, TONTINI A, MOR M, TARZIA G, LA RANA G, CALIGNANO A, GIUSTINO A, TATTOLI M, PALMERY M, CUOMO V, PIOMELLI D: Modulation of anxiety through blockade of anandamide hydrolysis. Nat Med 9: 76-81, 2003.

KATONA I, FREUND T: Multiple functions of endocannabinoid signaling in the brain. Annu Rev Neurosci 35: 529-558, 2012.

KIEFFER BL: Recent advances in molecular recognition and signal transduction of active peptides: receptors for opioid peptides. Cell Mol Neurobiol 15: 615-635, 1995.

LANGLET F, MULLIER A, BOURET SG, PREVOT V, DEHOUCK B: Tanycyte-like cells form a bloodcerebrospinal fluid barrier in the circumventricular organs of the mouse brain. J Comp Neurol 521: 3389-3405, 2013.

LAU BK, DREW GM, MITCHELL VA, VAUGHAN CV: Endocannabinoid modulation by FAAH and monoacylglycerol lipase within the analgesic circuitry of the periaqueductal grey. Br J Pharmacol 171: 5225-5236, 2014a.

LAU BK, VAUGHAN CW: Descending modulation of pain: the GABA disinhibition hypothesis of analgesia. Curr Opin Neurobiol 29: 159-164, 2014b.

LE MERRER J, BECKER JA, BEFORT K, KIEFFER BL: Reward processing by the opioid system in the brain. Physiol Rev 89: 1379-1412, 2009.

LONG JZ, LI W, BOOKER L BURSTON JJ, KINSEY SG, SCHLOSBURG JE, PAVÓN FJ, SERRANO AM, SELLEY DE, PARSONS LH, LICHTMAN AH, CRAVATT BF: Selective blockade of 2-arachidonoylglycerol hydrolysis produces cannabinoid behavioral effects. Nat Chem Biol 5: 37-44, 2009a.

LONG JZ, NOMURA DK, VANN RE, WALENTINY DM, BOOKER L, JIN X, BURSTON JJ, SIM-SELLEY LJ, LICHTMAN AH, WILEY JL, CRAVATT BF: Dual blockade of FAAH and MAGL identifies behavioral processes regulated by endocannabinoid crosstalk in vivo. Proc Natl Acad Sci U S A 106: 20270-20275, 2009 b.

LUK T, JIN W, ZVONOK A, LU D, LIN XZ, CHAVKIN C, MAKRIYANNIS A, MACKIE K: Identification of a potent and highly efficacious, yet slowly desensitizing CB1 cannabinoid receptor agonist. Br J Pharmacol 142: 495-500, 2004.

MACKIE K, HILLE B: Cannabinoids inhibit N-type calcium channels in neuroblastoma-glioma cells. Proc Natl Acad Sci U S A 89: 3825-3829, 1992.

MAIONE S, BISOGNO T, DE NOVELliS V, PALAZZO E, CRISTINO L, VALENTI M, PETROSINO S, GUGLIELMOTTI V, ROSSI F, DI MARZO V: Elevation of endocannabinoid levels in the ventrolateral periaqueductal grey through inhibition of fatty acid amide hydrolase affects descending nociceptive pathways via both cannabinoid receptor type 1 and transient receptor potential vanilloid type-1 receptors. J Pharmacol Exp Ther 316: 969-982, 2006.

MANZANARES J, CORCHERO J, ROMERO J, FERNANDEZ-RUIZ JJ, RAMOS JA, FUENTES JA: Pharmacological and biochemical interactions between opioids and cannabinoids. Trends Pharmacol Sci 20: 287-294, 1999.

MECHOULAM R, BEN-SHABAT S, HANUŠ L, LIGUMSKY M, KAMINSKI NE, SCHATZ AR, GOPHER A, ALMOG S, MARTIN BR, COMPTON DR: Identification of an endogenous 2-monoglyceride, present in canine gut, that binds to cannabinoid receptors. Biochem Pharmacol 50: 83-90, 1995.

MECHOULAM R, HANUŠ L, PERTWEE RG, HOWLETT AC: Early phytocannabinoid chemistry to endocannabinoids and beyond. Nat Rev Neurosci 15: 757-764, 2014.

MESTRE L, INIGO PM, MECHA M, CORREA FG, HERNA N, GÓMEZ-HERRERO M, LORÍA F, DOCAGNE F, BORRELL J, GUAZA C: Anandamide inhibits Theiler's virus induced VCAM-1 in brain endothelial cells and reduces leukocyte transmigration in a model of blood-brain barrier by activation of CB1 receptors. J Neuroinflammation 8: 102, 2011.

NAVIA-PALDANIUS D, AALTONEN N, LEHTONEN M, SAVINAINEN JR, TASCHLER U, RADNER FP, ZIMMERMANN R, LAITINEN JT: Increased tonic cannabinoid CB1R activity and brain region-specific desensitization of CB1R Gi/o signaling axis in mice with global genetic knockout of monoacylglycerol lipase. Eur J Pharm Sci 77: 180-188, 2015. 
NAWARRO M, CARRERA MR, FRATTA W, VALVERDE O, COSSU G, FATTORE L: Functional interaction between opioid and cannabinoid receptors in drug self-administration. J Neurosci 21: 5344-5350, 2001.

PANDEY R, MOUSAWY K, NAGARKATTI M, NAGARKATTI P: Endocannabinoids and immune regulation. Pharmacol Res 60: 85-92, 2009.

PANIKASHVILI D, SHEIN NA, MECHOULAM R, TREMBOVLER V, KOHEN R, ALEXANDROVICH A, SHOHAMI E: The endocannabinoid 2-AG protects the blood-brain barrier after closed head injury and inhibits mRNA expression of proinflammatory cytokines. Neurobiol Dis 22: 257-264, 2006.

PERLIKOWSKA R, PIEKIELNA J, FICHNA J, DO-REGO JC, TOTH G, JANECKI T, JANECKA A: Pharmacological properties of novel cyclic pentapeptides with $\mu$-opioid receptor agonist activity. Med Chem 10: 154-161, 2014.

PERTWEE RG: The pharmacology of cannabinoid receptors and their ligands: an overview. Int $J$ Obes (Lond) 30 (Suppl 1): S13-S18, 2006.

PETROSINO S, PALAZZO E, DE NOVELlis V, BISOGNO T, ROSSI F, MAIONE S, Di MARZO V: Changes in spinal and supraspinal endocannabinoid levels in neuropathic rats. Neuropharmacology 52: 415-422, 2007.

PETRUSZ P, MERCHENTHALER I, MADERDRUT JL: Distribution of enkephalin-containing neurons in the central nervous system. Chapter VI. In: Handbook of Chemical Neuroanatomy. GABA and Neuropeptides in the CNS. Part I. BJÖRKLUND A, HÖKFELT T (eds), Elsevier, Amsterdam, 1985, pp 273.

PRICE TJ, HELESIC G, PARGHI D, HARGREAVES KM, FLORES CM: The neuronal distribution of cannabinoid receptor type 1 in the trigeminal ganglion of the rat. Neuroscience 120: 155-162, 2003.

PRZEWLOCKI R, PRZEWLOCKA B: Opioids in chronic pain. Eur J Pharmacol 429: 79-91, 2001.

ROBERTS JD, GENNINGS C, SHIH M: Synergistic affective analgesic interaction between delta(9)-tetrahydrocannabinol and morphine. Eur J Pharmacol 530: 54-58, 2006.

ROKYTA R, HŘIB R, LEJČKO J: Konopí pro léčebné účely. (In Czech) In: Opioidy, KOZÁK J, LEJČKO J, VRBA J (eds), Prague, 2018, pp 310-322.

ROKYTA R: Patofyziologie a mechanimus účinku opioidů. (In Czech) In: Opioidy, KOZÁK, LEJČKO J, VRBA J (eds), Prague, 2018, pp 67-74.

SALIO C, FISCHER J, FRANZONI MF, MACKIE K, KANEKO T, CONRATH M: CB1-cannabinoid and mu-opioid receptor co-localization on postsynaptic target in the rat dorsal horn. Neuroreport 12: 3689-3692, 2001.

SUGIURA T, KONDO S, SUKAGAWA A, NAKANE S, SHINODA A, ITOH K, YAMASHITA A, WAKU K: 2-Arachidonoylglycerol a possible endogenous cannabinoid receptor ligand in brain. Biochem Biophys Res Commun 215: 89-97, 1995.

THAM SM, ANGUS JA, TUDOR EM, WRIGHT CE: Synergistic and additive interactions of the cannabinoid agonist CP55,940 with mu opioid receptor and alpha2-adrenoceptor agonists in acute pain models in mice. Br J Pharmacol 144: 875-884, 2005.

UEDA N, YAMAMOTO S: Anandamide amidohydrolase (fatty acid amide hydrolase). Prostaglandins Other Lipid Mediat 61: 19-28, 2000.

VAUGHAN CW, MCGREGOR IS, CHRISTIE MJ: Cannabinoid receptor activation inhibits GABA-ergic neurotransmission in rostral ventromedial medulla neurons in vitro. Br J Pharmacol 127: 935-940, 1999.

VEENING JG, BARENDREGT HP: The regulation of brain states by neuroactive substances distributed via the cerebrospinal fluid; a review. Cerebrospinal Fluid Res 7: 1, 2010.

VIGANO D, RUBINO T, PAROLARO D: Molecular and cellular basis of cannabinoid and opioid interactions. Pharmacol Biochem Behav 81: 360-368, 2005.

WEISS AL, EHRHARDT KP, TOLBA R: Atypical facial pain: a comprehensive, evidence-based review. Curr Pain Headache Rep 21: 8, 2017.

WILSON-POE A, POCIUS E, HERSCHBACH M, MORGAN MM: The periaqueductal gray contributes to bidirectional enhancement of antinociception between morphine and cannabinoids. Pharmacol Biochem Behav 103: 444-449, 2013.

WOODHAMS SG, CHAPMAN V, FINN DP, HOHMANN AG, NEUGEBAUER V: The cannabinoid system and pain. Neuropharmacology 124: 105-120, 2017. 
ZADINA JE, HACKLER L, GE LJ, KASTIN AJ: A potent and selective endogenous agonist for the mu-opiate receptor. Nature 386: 499-502, 1997.

ZUBRZYCKA M, JANECKA A, KOZIOŁKIEWICZ W, TRACZYK WZ: Inhibition of tongue reflex in rats by tooth pulp stimulation during cerebral ventricle perfusion with (6-11) substance P analogs. Brain Res 753: 128-132, 1997.

ZUBRZYCKA M, JANECKA A: Effect of cerebral ventricles perfusion with naloxone on trigemino-hypoglossal reflex in rats. Regul Pept 97: 7-13, 2001.

ZUBRZYCKA M, JANECKA A: Substance P content in the cerebrospinal fluid and fluid perfusing cerebral ventricles during elicitation and inhibition of trigemino-hypoglossal reflex in rats. Brain Res 941: 29-33, 2002.

ZUBRZYCKA M, FICHNA J, JANECKA A: Inhibition of trigemino-hypoglossal reflex in rats by oxytocin is mediated by mu and kappa opioid receptors. Brain Res 1035: 67-72, 2005.

ZUBRZYCKA M, JANECKA A: Interactions of galanin with endomophin-2, vasopressin and oxytocin in nociceptive modulation of the trigemino-hypoglossal reflex in rats. Physiol Res 57: 769-776, 2008.

ZUBRZYCKA M, JANECKA A: Effect of tooth pulp and periaqueductal central gray electrical stimulation on $\beta$-endorphin release into the fluid perfusing the cerebral ventricles in rats. Brain Res 1405: 15-22, 2011.

ZUBRZYCKA M, SZEMRAJ J, JANECKA A: Effect of tooth pulp and periaqueductal central gray stimulation on the expression of genes encoding the selected neuropeptides and opioid receptors in the mesencephalon, hypothalamus and thalamus in rats. Brain Res 1382: 19-28, 2011.

ZUBRZYCKI M, JANECKA A, ZUBRZYCKA M: Trigemino-hypoglossal somatic reflex in the pharmacological studies of nociception in orofacial area. Acta Neurobiol Exp 75: 253-263, 2015.

ZUBRZYCKI M, JANECKA A, LIEBOLD A, ZIEGLER M, ZUBRZYCKA M: Effects of centrally administered endocannabinoids and opioids on orofacial pain perception in rats. Br J Pharmacol 174: 3780-3789, 2017. 